\title{
NON-COGNITIVE ABILITIES AND FINANCIAL DELINQUENCY: THE ROLE OF SELF-EFFICACY IN AVOIDING FINANCIAL DISTRESS
}

\author{
Camelia M. Kuhnen \\ Brian T. Melzer \\ Working Paper 23028 \\ http://www.nber.org/papers/w23028 \\ NATIONAL BUREAU OF ECONOMIC RESEARCH \\ 1050 Massachusetts Avenue \\ Cambridge, MA 02138 \\ January 2017
}

Funding for this paper was provided by the University of North Carolina, and Northwestern University. We thank Benjamin Keys, Tom DeLeire, Lindsey Leininger, seminar participants at U.C. Berkeley, the University of Virginia, NC State University, participants at the AEA 2014 meeting, the 2014 FDIC Consumer Research Symposium and the 2015 University of Alberta Frontiers in Finance conference for helpful comments and discussion. All remaining errors are ours. The views expressed herein are those of the authors and do not necessarily reflect the views of the National Bureau of Economic Research.

NBER working papers are circulated for discussion and comment purposes. They have not been peer-reviewed or been subject to the review by the NBER Board of Directors that accompanies official NBER publications.

(C) 2017 by Camelia M. Kuhnen and Brian T. Melzer. All rights reserved. Short sections of text, not to exceed two paragraphs, may be quoted without explicit permission provided that full credit, including $\odot$ notice, is given to the source. 
Non-Cognitive Abilities and Financial Delinquency: The Role of Self-Efficacy in Avoiding Financial Distress

Camelia M. Kuhnen and Brian T. Melzer

NBER Working Paper No. 23028

January 2017

JEL No. D03,D1,D14,D84,G02

\begin{abstract}
$\underline{\text { ABSTRACT }}$
We investigate a novel determinant of household financial delinquency, namely, people's subjective expectations regarding the cost-benefit trade-off in default decisions. These expectations are determined by individuals' self-efficacy, which is a non-cognitive ability that measures how strongly people believe that their effort will influence future outcomes. Using longitudinal household survey data, we show that people with higher self-efficacy, measured earlier in life, are less likely to be financially delinquent later on and to face consequences such as losing assets or access to traditional credit markets, are more likely to prepare for dealing with potential adverse shocks such as a job loss or a health event, and when faced with such shocks, are less likely to become financially delinquent. Complementing prior findings regarding the effects of cognitive abilities, financial literacy and education on economic behavior, our evidence suggests that non-cognitive abilities have an important role in household financial decision making.
\end{abstract}

Camelia M. Kuhnen

University of North Carolina

Kenan-Flagler Business School

300 Kenan Center Drive, MC \#4407

Chapel Hill, NC 27599

and NBER

camelia_kuhnen@kenan-flagler.unc.edu

Brian T. Melzer

Kellogg School of Management

Northwestern University

2001 Sheridan Road

Evanston, IL 60208

b-melzer@kellogg.northwestern.edu 


\section{Introduction}

A large number of U.S. households face financial fragility. In 2015, the Federal Reserve Board found that nearly half of adults are ill-prepared for a financial disruption and would struggle to cover emergency expenses should they arise. ${ }^{1}$ At the same time, nearly three quarters of American households have debt outstanding and, over the past two decades, an increasing share of borrowers have come from the bottom of the income and net worth distributions, where income and savings buffers are small or absent. ${ }^{2}$ The financial fragility of American households was particularly evident in the recent financial crisis, when one in twelve households defaulted on outstanding loans and delinquent debt became an issue of macroeconomic significance. But why is it that only some households become financially delinquent, but many others do not?

Existing work has characterized household default decisions as the result of a trade-off between costs, such as loss of collateral or credit market exclusion, and benefits, such as freeing up resources for consumption (e.g., Chatterjee et al. (2007)). Here, we present evidence suggesting that individuals' subjective perception of this trade-off is also an important driver of how these individuals manage their liabilities. Specifically, we examine the role of subjective beliefs that people have regarding the effect of their actions on future outcomes on these individuals' financial delinquency behavior.

People vary in how strongly they believe that their actions or effort influence what the future will bring. This characteristic, known as self-efficacy, is one of the non-cognitive abilities that have been shown to improve individuals' educational and labor market attainment (Heckman et al. (2006), Lindqvist and Vestman (2011)). To see how self-efficacy can also impact financial delinquency, consider a situation where a person has to spend effort to avoid

\footnotetext{
${ }^{1}$ Specifically, forty-six percent of U.S. adults either could not cover an emergency expense costing $\$ 400$, or would cover it by selling something or borrowing money. The full report on the Survey of Household Economics and Decisionmaking is available at: http://www.federalreserve.gov/2015-report-economic-wellbeing-us-households-201605.pdf

${ }^{2}$ The share of households with debt substantially exceeds, for example, the shares with stock holdings $(48.8 \%)$ and retirement savings accounts (49.2\%) (Survey of Consumer Finances, 2013).
} 
a poor financial outcome. For example, the person might need to find ways to reduce spending today, or get a second job, in order to avoid defaulting on their credit card or mortgage payments in the future. A simple way to conceptualize this is as an effort choice problem, where providing effort is costly but it leads to an increase in the chance that the person will avoid a poor outcome later. People with lower self-efficacy scores have lower estimates for this increase than people with higher scores and thus choose to spend less effort, which will lead to a lower probability of avoiding a bad outcome. Empirically, this setting implies that individuals with lower self-efficacy will have higher rates of financial distress, will spend less effort to prepare for potential adverse shocks, and upon encountering such shocks, will be more likely to become delinquent.

To study the relationship between self-efficacy and financial delinquency, we use the National Longitudinal Survey of Youth (NLSY) dataset. Self-efficacy scores of individuals tracked in the NLSY are obtained as part of the regular interviews that participants complete every two years. The NLSY data also provides a rich set of demographic characteristics, as well as labor market outcomes and financial variables including indicators of financial delinquency, consequences of delinquency, such as the loss of assets and the loss of access to credit, as well as measures of financial preparedness and indicators of the occurrence of negative cash flow shocks.

Our empirical analysis provides evidence consistent with our hypotheses regarding the effects of self-efficacy on financial distress. We find that lower self-efficacy scores predict a higher probability of financial delinquency later in life, and a higher probability of loss of assets and loss of access to traditional credit. Moreover, we find that individuals with higher self-efficacy scores expend more effort preparing to mitigate potential adverse financial shocks, and when such shocks occur, they are less likely to become delinquent. The effects of self-efficacy are substantial and robust, and are not explained by differences in gender, race, cognitive ability, educational attainment and income, risk and time preferences.

We use two measures to capture people's delinquency status in a particular year. First, 
we examine whether the NLSY respondents were at least 60 days behind making payments on their credit card, vehicle loan, mortgage or other type of debt outstanding. Second, we examine whether they were at least 60 days late paying their utilities, medical bills or other type of bills. We find that delinquency rates for the people with the best self-efficacy scores in our sample are lower by $5 \%$ than the delinquency rates of people with the lowest self-efficacy scores. This is a sizeable difference, given that in our sample the average delinquency rates are roughly $12 \%$ for either delinquency measure. Analyzing the consequences of financial delinquency, we document that individuals with the highest self-efficacy scores, relative to those with the lowest scores, have a $3 \%$ lower chance of having accounts in collection, an outcome whose frequency in the data is about $18 \%$, and a $2 \%$ lower chance to go through foreclosure, asset repossession or bankruptcy, which occurs in $3 \%$ of our observations. The higher self-efficacy individuals have a $3 \%$ to $5 \%$ better chance to have access to traditional credit instruments, which represents up to a third of the frequency of traditional credit access we observe in the sample, and their probability of using non-standard credit, specifically payday loans, is $3 \%$ less than that of low self-efficacy individuals, a sizeable difference given the $6 \%$ payday usage frequency in our sample.

We investigate potential mechanisms that can drive the correlation we observe between self-efficacy earlier in life, and financial distress - that is, delinquency and its consequences - later on. We first test whether unobserved intra-family insurance, or parental inputs, can explain our findings, as it is possible that individuals with higher self-efficacy scores may also have families who can offer financial help in difficult times, and thus such individuals will be more likely to avoid financial distress. We use the fact that in the NLSY data there are many individuals who are part of sibling groups - namely, they have the same mother and who exhibit differences in self-efficacy. We re-estimate our main models for predicting financial distress using mother fixed effects as additional controls, and confirm that intrafamily insurance can not fully account for the effects of self-efficacy on financial delinquency and its consequences in terms of asset loss and credit access. We then test the specific 
predictions driven by our theoretical motivation, namely, that individuals with higher selfefficacy will exert more effort to avoid bad outcomes, and when faced with negative financial shocks, will fare better. As predicted, we find that a person's preparedness to weather financial shocks increases with self-efficacy, by a fifth to a half between those with the best and the worst self-efficacy scores, depending on the preparedness measures used. These measures include indicators as to whether the person has emergency funds saved up, has health insurance or long-term care insurance, or has worked on their financial plans for retirement. Moreover, we document that individuals with highest self-efficacy are $8 \%$ to $13 \%$ less likely than those with the lowest scores to become financially delinquent after being faced with negative financial shocks stemming from job loss or from a health-related event.

Our results have implications for the understanding and modeling of household default decisions. Economic models characterize default as a strategic decision taken upon considering the trade-off between the benefit of expunging remaining debt payments and freeing up resources for other consumption, and the costs of credit market exclusion, forgone collateral and social stigma. Studies have examined the importance of strategic default as a mechanism to eliminate debt in the absence of liquidity shocks (Deng et al. (2000), Foote et al. (2008), Campbell and Cocco (2015)), and variations in costs and benefits stemming from the legal environment (Fay et al. (2002)) or cultural norms (Guiso et al. (2013)) have also been shown to predict default outcomes. Additionally, household financial default has been found to be driven by the occurrence of income and expenditure shocks (Elul et al. (2010), Gross and Notowidigdo (2011), Hsu et al. (2014)). Our insight is that differences in individuals' perception of the costs and benefits in the standard trade-off play a key role in financial distress outcomes. Our findings imply that the typical sources of household-level heterogeneity in theoretical models of default (e.g., Chatterjee et al. (2007)), namely, varying time preferences and costs from credit market exclusion - exclude an important factor that influences financial distress outcomes. While agents might still attempt to optimize their actions, their subjective beliefs could matter in how they solve debt-related problems. 
The evidence documented here suggests that non-cognitive abilities are important for financial decisions and outcomes, and complements the findings of the recent literature in economics and psychology regarding the significant role played by non-cognitive skills on educational attainment (Heckman et al. (2006), Cadena and Keys (2013), Cadena and Keys (2015)), wages (Lindqvist and Vestman (2011)), and health outcomes (Taylor and Seeman (2000)). Moreover, our results complement the finance literature focused on the role of cognitive abilities on household outcomes. This literature has shown that better cognitive skills predict better outcomes in terms of mortgage delinquency, credit card usage, loan choices, and savings and investment behavior (Gerardi et al. (2013), Agarwal and Mazumder (2013), Stango and Zinman (2009), Grinblatt et al. (2011)). Financial literacy skills help individuals choose better investment portfolios and plan better for retirement (Lusardi and Mitchell (2009), Choi et al. (2010)). Education has positive effects on financial market participation, credit market access, and credit management (Campbell (2006), Ru and Schoar (2016), and Cole et al. (2012)). We contribute to this line of work in household finance by showing that non-cognitive skills, in particular people's capacity to believe that they can influence their future through their effort, are also helpful for attaining good financial outcomes in life.

Our paper also adds to the emerging literature regarding the connection between subjective expectations and household financial decisions. Individuals who are moderately optimistic about their life work harder, invest more in equities and have more savings (Puri and Robinson (2007)). People who believe their future is not under their control are more likely to lack interest in learning about investment options, to have low savings, and to be indebted over long horizons (Shapiro and Wu (2011), Cole et al. (2012), Caputo (2012)). Also, subjective expectations about macroeconomic conditions (rather than about one's personal situation), which are driven by broad economic developments (Greenwood and Shleifer (2014), Malmendier and Nagel (2016), Kuchler and Zafar (2016)), as well as by people's personal socieoeconomic situation (Kuhnen and Miu (forthcoming)), have been shown to 
predict households' investment decisions (Kezdi and Willis (2011)). An interesting question for future work is whether subjective expectations about macroeconomic outcomes, and those about one's personal outcomes - for example, self-efficacy - are related, and how much these two types of expectations contribute to the observed variation across households in their financial decisions.

\section{Self-efficacy and financial decision making}

People's capacity to believe that they can influence future outcomes through their actions has been captured by three related concepts in psychology: locus of control (Rotter (1966)), the sense of mastery (Pearlin et al. (1981)) and self-efficacy (Bandura (1986)). High self-efficacy, mastery or having an internal locus of control have been shown to predict better physical and mental health (Taylor and Seeman (2000)), better academic achievements (Kalil and Khalid (2010)), higher job satisfaction and job performance (Judge and Bono (2001)), and a less negative impact of encountering economic hardship or being in a low-income group on psychological well-being and physical health (Lachman and Weaver (1998), Pudrovska et al. (2005)). In our analysis, due to data availability, we focus on the Pearlin mastery measure.

\subsection{Measuring self-efficacy}

The Pearlin Mastery score is compiled from responses to a battery of seven statements and is designed to measure mastery, or self-efficacy - that is, the extent to which individuals perceive themselves to be in control of their lives and future outcomes. For each statement, the respondent ranks the strength of their agreement on a scale of one (strongly agree) to four (strongly disagree). The seven Pearlin statements are: (1) "No way I can solve some of the problems I have."; (2) "Sometimes I feel that I am being pushed around in life."; (3) "I have little control over the things that happen to me."; (4) "I can do just about anything I really set my mind to."; (5) "I often feel helpless in dealing with the problems of life."; (6) 
"What happens to me in the future mostly depends on me."; (7) "There is little I can do to change many of the important things in my life."

After reversing the scoring for items 4 and 6 so that higher scores correspond to greater mastery or self-efficacy, the 7 scores are summed to give a total raw score ranging between 7 and 28. In our analysis, we assign each individual to a percentile in the distribution of these raw scores, and use this percentile as our self-efficacy measures, to help with interpreting the magnitude of the estimated effects of self-efficacy on variables related to financial distress. Using the raw Pearlin score, rather than the percentile measure, in our regressions leads to similar results in terms of economic importance and statistical significance.

\subsection{How can self-efficacy affect the likelihood of financial distress?}

In this section, we provide a simple theoretical framework for understanding the role of selfefficacy in an individual's decision to default on outstanding debt. We consider an effort choice problem describing a situation where a person has to spend effort to avoid a poor financial outcome, for instance, by identifying ways to cut spending today, or to secure additional income, in order to avoid defaulting on their credit card or mortgage payments in the future. In this situation, increasing the effort $e$ provided has some cost $c(e)$ but it increases the probability that the person will obtain a high $(H)$ rather than a low $(L)$ outcome later. The actual probability of obtaining the high outcome $H$ is the effort level $e$, and the probability of obtaining the low outcome $L$ is $1-e$. However, people believe that the probability of outcome $H$ is $e * s$, where $s \in[0,1]$ measures their self-efficacy. If $s=1$, people correctly assess that the probability of getting the high outcome is equal to the effort $e$ they provide. If $s<1$, people have a pessimistic assessment of the impact their effort has on the probability of getting the high outcome.

The person chooses the effort level $e$ to maximize the perceived benefit minus the cost of effort, i.e., they maximize the expression $-c(e)+\beta[e s H+(1-e s) L]$, where $\beta$ captures

the person's patience. Assuming the cost function is $c(e)=\frac{\gamma e^{2}}{2}$, with $\gamma>0$, the first order 
condition implies that the effort level selected is $e^{*}=\frac{\beta s(H-L)}{\gamma}$. Hence the probability that the low outcome $L$ is realized will be 1 for the lowest self-efficacy (i.e., $s=0$ ) people and will be $1-\frac{\beta(H-L)}{\gamma}$ for the highest self-efficacy (i.e., $s=1$ ) ones. Therefore, we have a simple expression for how differences in the level of self-efficacy should relate to differences in the observed frequency of low outcomes, such as distress events in our data. Namely, $\operatorname{Pr}\{L$ outcome if $s=0\}-\operatorname{Pr}\{L$ outcome if $s=1\}=\frac{\beta(H-L)}{\gamma}$. Equivalently, this can be expressed as: $\frac{d \operatorname{Pr}\{L \text { outcome }\}}{d s}=-\frac{\beta(H-L)}{\gamma}<0$.

This simple example provides the intuition for our main empirical predictions. Namely, we expect to observe in the data that lower self-efficacy is associated with a higher probability of financial distress, and with a lower level of effort spent preparing to avoid delinquency.

\section{$3 \quad$ Data and summary statistics}

\subsection{Data}

Our primary data source is the National Longitudinal Survey Youth 1979, Child and Young Adult sample (NLSY79CYA), a longitudinal survey that follows the children of women in the original NLSY 1979 sample throughout childhood and into adulthood. The NLSY79CYA survey, which is administered every two years, began in 1986 and continues today, with data released through the 2014 interview. The survey questionnaire has two components, a child questionnaire administered to those age 14 or younger and a young adult questionnaire administered to those age 15 and older. The child survey focuses on the family and schooling environments, and the child's health as well as his cognitive, emotional and social development, while the young adult survey continues to focus on schooling, psychological development and social development, but also tracks respondents marital history, employment history and financial history as they move into adulthood. Despite the label young adult, the latter questionnaire is used for sample members throughout adulthood, which means that by 2014, we observe a number of sample members that are well into their 30 s. 
The original NLSY79 survey followed roughly 13,000 individuals, and by 2014 the Child and Young sample on which we focus includes 11,512 individuals. In our analysis of financial distress and self-efficacy, we focus on adults that are 21 years old or older as of 2014, at which point they are likely to be financially independent. This portion of the sample includes 6031 individuals for which we have demographic information. Overlapping subsets of these individuals are present in the 2010, 2012 and 2014 waves of the survey. For parts of our analysis we are also able to bring in data from the original NLSY79 sample, which contains older adults, who are approaching retirement age. This original NLSY79 sample does not have detailed information about financial delinquency or financial distress in general, but it does contain some data items that capture credit demand and also that provide information about these households' financial preparedness efforts. Hence in the analysis we will supplement the results based on the NLSY79CYA sample of younger adults, for which we have good measures of financial delinquency and fragility, with several results based on the older sample of adults in the NLSY79 original dataset.

\subsection{Summary Statistics}

Summary statistics regarding our sample are reported in Table 1. The panel data set we use in the analysis covers approximately 12,000 person-year observations, across years 2010, 2012 and 2014. Our independent variable of interest is the Pearlin Mastery score, a measure of self-efficacy, obtained in each wave of interviews. We assign each individual to a percentile in the distribution of the Pearlin scores in our sample, based on the average of their Pearlin scores prior to the years when financial outcomes are measured.

To quantify people's time and risk preferences, we obtain measures of the participants' patience and propensity to avoid risky behaviors, based on interviews conducted in childhood. The patience score ranges from 1 to 3, with 3 being the best, and it refers to the assessment of the degree to which people exhibited impulsive behaviors during NLSY interviews. The same measure of patience has been previously used by DellaVigna and Paserman (2005) to 
document that more impatient individuals exert less effort to search for jobs and have longer unemployment spells. As our measure for the propensity to avoid risky behaviors, we use the first principal component of the person's normalized scores on three scales available in the survey (risk-taking, excitement and danger).

To assess people's cognitive ability, we use the person's scores on the Peabody Individual Achievement Test (PIAT), which tests math ability as well as reading recognition and reading comprehension. These measures of cognitive ability are taken throughout childhood, and we focus on the last available measure, which most commonly is taken at age 13 or 14 . The PIAT ability scores are measured in percentiles and normalized by age group relative to scores in a national sample in 1968. The first principal component of there three scores is our measure of the person's cognitive ability.

Turning to education, in $19 \%$ of our person-year observations participants report having a college or graduate degree, in $8.53 \%$ of observations they report having completed some college, in $55.26 \%$ of observations they report having only a high school diploma, and in $17.25 \%$ of observations participants report failing to complete high school. The rate of college degree completion is lower than U.S. averages because some sample members are still in their 20s. The average of the respondent's age is 27 years, with a standard deviation of 4.20 years. Approximately $48 \%$ of the sample are men.

Racially, the composition of the sample is tilted toward minorities, with both blacks (34.90\% of the sample) and hispanics (21.85\% of the sample) being intentionally oversampled in the original NLSY data set.

The average person is in a household that includes just over three people, has income of about $\$ 29,000$ and debt of $\$ 21,770$. The distribution of debt is highly skewed, as some households have significant debt, mainly due to mortgages, while about $53 \%$ of the sample have debt close to zero. Within our sample, the incidence of having a credit card, a vehicle loan or a mortgage is $41.89 \%, 30.93 \%$ and $15.21 \%$, respectively.

Among household financial variables, the data on household debt are quite rich, while the 
data on assets are less comprehensive and detailed (in particular, the survey lacks information on financial asset holdings). Since 2000, each respondent to the young adult questionnaire reports the outstanding balances on credit card, vehicle and mortgage loans, as well as the estimated value of the underlying collateral for the latter two categories. In 2010, 2012 and 2014, various questions about credit delinquency, asset loss, difficulties accessing credit, and financial preparedness were added to the survey. These measures comprise the key dependent variables in our study.

Specifically, we can observe whether, as of 2010, 2012 and 2014, a person has been at least 60 days behind on payments for their credit card, vehicle loans, other type of loans, or bills over the last year. The mortgage delinquency measure differs slightly in that it measures delinquency over the 2 years rather than the prior 12 months. We also observe if the person had assets repossessed or their property foreclosed in the prior 2 years, and whether in the prior 12 months, the person had accounts sent to a bill collector, had filed for bankruptcy, or had resorted to borrowing from payday lenders. We also use the respondents' answers to questions relating to whether they have emergency funds available (this data item is only available in 2012 and 2014), and whether they have health insurance, as measures for the extent to which they prepare for potential adverse shocks that can impact their financial situation later in life.

Overall, in our person-year sample of approximately 12,000 observations we observe that the frequency of being delinquent as indicated by being late making debt payments or being late paying bills is $11.35 \%$ and $12.50 \%$, respectively. If we measure delinquency as being late with making either of these two types of payments, the frequency of delinquency is $18.81 \%$. The incidence of having accounts sent to collection agencies is $18.20 \%$, and that of experiencing asset foreclosure or repossession, or bankruptcy is $3.15 \%$. Respondents indicate having a credit card, a vehicle loan, or a mortgage in $41.89 \%, 30.93 \%$, and $15.21 \%$, of our person-year observations, respectively, and in $5.86 \%$ of observations, they state that they have borrowed money from a payday lender. In $3.67 \%$ of the person-year observations respondents report 
having emergency funds saved up, and in $34.28 \%$ of observations, respondents report having no health insurance.

\section{Results}

\subsection{Self-efficacy and financial delinquency}

As predicted, we find that there is a negative relationship between a person's self-efficacy earlier in life, and their likelihood of being financially delinquent later on. This result can be seen in the simple plot in Figure 1, which presents the incidence of financial delinquency in a given survey year, as a function of the self-efficacy of respondents measured in years prior to when the delinquency status is assessed. The financial delinquency status indicator is defined as 1 if the respondent indicated being late paying their debt (Late debt $t_{i t}$ ), or paying their bills (Late bills $s_{i t}$ ), and it is 0 otherwise. The variable Late debt $t_{i t}$ captures whether person $i$ in year $t$ reports being late with making the required payments on their credit card, vehicle loan, mortgage or other type of debt outstanding, and Late bills $s_{i t}$ captures whether the person reports being late with paying their medical, utilities or other bills. The figure shows the average delinquency rates, as well as standard error bars, for each of five categories of Pearlin scores, each containing approximatively one fifth of the 12,196 person-year observations in our sample. The incidence of financial delinquency decreases significantly from the lowest self-efficacy levels to the highest. For people in the lowest of the five bins of self-efficacy (those with raw Pearlin scores below 20), the average incidence of delinquency is $23.11 \%$, whereas for those in the highest of the five bins of self-efficacy (those with raw Pearlin scores greater than 24) the average incidence of delinquency is $13.96 \%$. The difference between these two rates of delinquency is significant at $p<0.01$.

We then further examine the strength of this relationship between self-efficacy and delinquency in regression models where we measure self-efficacy in a finer way, using a person's

percentile in the Pearlin score distribution, and where we gradually add in predictors of 
delinquency such as age, race and gender, which are arguably exogenous, as well as other control variables including measures of the person's cognitive ability, risk and time preferences, education, income and indebteness status. In line with the pattern observed in Figure 1, in the linear probability models estimated in Table 2 we document that there is a significant negative correlation between a person's self-efficacy earlier in life, and their likelihood of later on being financially delinquent. ${ }^{3}$ The first indicator of financial delinquency that we use in the analysis, Late debt $t_{i t}$, captures whether person $i$ in year $t$ reports being late with making the required payments on their credit card, vehicle loan, mortgage or other type of debt outstanding. The second indicator, Late bills $s_{i t}$ captures whether the person reports being late with paying their bills (medical, utilities or other). The correlation between Self-efficacy $i$ and either of these two indicators of financial delinquency is negative and significant in all specification in the table, for any set of control variables we include. In the most stringent specification which is the one that includes the full set of control variables, we document that an increase in the self-efficacy percentile from $0 \%$ to $100 \%$ corresponds to a $5.56 \%$ drop in the probability of being late with making debt payments $(p<0.01)$, and to a drop of $5.28 \%$ in the probability of being late with bill payments $(p<0.01)$. These effects are sizeable in light of the observed frequency of delinquency along these two dimensions in our sample, of about $12 \%$, as reported in Table 1.

Unsurprisingly in light of prior work in household finance regarding the effects of education and literacy on economic behavior, we also find that respondents with lower education levels relative to the reference group of graduate degree holders have a significantly higher probability of being delinquent. Moreover, we find that people who are more risk averse and more patient have lower delinquency rates. Higher incomes lead to a lower rate of being delinquent in terms of paying bills, but, all else equal, do not influence to the probability of being late making debt payments. Demographic factors are also important, in that older people, women and non-white respondents have higher rates of financial delinquency.

\footnotetext{
${ }^{3}$ All of our results are virtually unchanged if we use probit models instead of linear probability models. We use OLS simply due to the ease of interpretation of the estimated coefficients in these models.
} 


\subsection{Self-efficacy and consequences of financial delinquency}

In Tables 3 and 4 we examine the relationship between a person's self-efficacy earlier in life, and the likelihood of facing negative consequences caused by financial delinquency. In Table 3 we focus on indicators of asset loss, whereas in Table 4 we focus on indications of loss of access to traditional credit.

As expected, in Table 3 we document that, controlling for age, race, gender, education and income, as well as measures of cognitive ability, risk and time preference, individuals with higher levels of self-efficacy have a $2.84 \%$ lower probability of having accounts in collection $(p<0.1)$, and a $1.54 \%$ lower probability of having a property foreclosed, assets repossessed, or being bankrupt $(p<0.05)$. These effects are large, given that the frequencies with which these two categories of outcomes occur in the data, shown in Table 1, are roughly $18 \%$ and $3 \%$, respectively.

In Table 4 we document that in terms of access to credit, lower self-efficacy corresponds to worse outcomes. In the first two columns in the table we use data from the NLSY79 older adults dataset, which provides information (not available in our main dataset covering younger adults) in recent waves of the survey as to whether the responded applied for credit, and whether contingent on applying, they were rejected. Including the full set of controls deployed so far in the analysis, the regression in the first column of the table shows that self-efficacy does not predict whether people apply for credit. However, the regression in the second column indicates that among people who applied for credit, the rejection rate is significantly lower among people with higher self-efficacy. A increase in the self-efficacy percentile from $0 \%$ to $100 \%$ corresponds to a drop of $10.18 \%$ in the credit application rejection probability $(p<0.01)$. In other words, we observe that in the sample of old adults, low self-efficacy corresponds to a lower probability of accessing traditional credit. The same conclusion can be drawn for our main sample, that is, for younger adults, for which we can measure whether they have access to traditional credit instruments, and whether they resort to non-standard credit sources - specifically, payday loans. Columns three to five in Table 
4 have as dependent variables indicator variables that measure whether the respondent has a credit card, a car loan, or a mortgage loan. The dependent variable in the last column in the table indicates whether the person has taken out a payday loan. We document that increasing the self-efficacy percentile from $0 \%$ to $100 \%$ increases the probability of having traditional credit sources by $3.76 \%$ for credit cards, $5.24 \%$ for vehicle loans, and $4.95 \%$ for mortgages, respectively (all significant at $p<0.05$ or better). Moreover, the same change in self-efficacy corresponds to a drop of $2.90 \%$ in the probability that the person has taken out a payday loan $(p<0.01)$, an effect equal to half of the observed $5.86 \%$ rate of payday lending usage in our sample.

\subsection{Potential mechanisms underlying the effects of self-efficacy on financial delinquency and its consequences}

Our theoretical framework implies that the mechanism explaining the connection between self-efficacy and distress is based on effort provision. Namely, higher self-efficacy people believe that their effort has a high impact on their financial situation, and thus will provide a high level of effort to avoid a bad outcome. However, outside of our framework, another explanation for our findings so far is that there are omitted factors that drive both selfefficacy and the distress likelihood. An prominent such factor is parental investment, or intra-family insurance. Specifically, it is possible that individuals with high levels of selfefficacy grow up in families where parents invest more in their offspring in terms of character formation, but also, perhaps, offer more financial support to children should they encounter adversity in life. In Tables 5 and 6 we examine whether differential parental investment can explain the relationship we have documented between self-efficacy and financial delinquency and its consequences. In the regression models in Table 5 we take advantage of the fact that many of the individuals in our sample have siblings, and thus we can include mother fixed-effects as additional determinants of financial delinquency and its consequences. For all of the outcomes we examine - being late making loan payments or paying bills, losing 
assets, or the ability to access traditional credit - the effects of self-efficacy are statisticaly significant and similar in sign and magnitude to those documented in Tables 2,3 and 4 . In other words, this analysis suggests that intra-family insurance can not fully account for the effects of self-efficacy on financial delinquency and its consequences in terms of asset loss and credit access. Moreover, when we split the data based on the net worth of the respondents' mothers in Table 6, we find that the largest effect of self-efficacy on the likelihood of financial delinquency, as measured by the Late debt $t_{i t}$ indicator, is obtained among individuals whose mothers are in the lowest tertile in terms of net worth. For these individuals, the difference in the probability of delinquency between those with the highest and those with the lowest self-efficacy scores is $8.91 \%(p<0.01)$, which is larger than the average effect of $5.56 \%$ found in the main specification in Table 2. Among individuals with mothers in the wealthiest tercile of the sample, self-efficacy has a negative impact on delinquency, but the estimated effect is smaller (a drop in delinquency of 3.01\% from the highest to the lowest self-efficacy levels) and statistically not different from zero. These results suggest that self-efficacy is particularly helpful to individuals who face more economically adverse environments early in life.

We then document evidence consistent with the mechanism proposed in our theoretical framework, namely, that individuals with higher self-efficacy will exert more effort to avoid bad outcomes. Specifically, in Tables 7 and 8 we show that a person's preparedness to weather financial shocks increases with self-efficacy. Moreover, in Table 9 we document that individuals with higher self-efficacy are more likely than the rest of the population to avoid financial delinquency after being faced with negative financial shocks stemming from job loss or from a health-related event.

To measure a person's effort in making preparations to be able to deal with potential adverse financial events, we use several variables available in the NLSY79CYA sample, and complement those with other measures available in the NLSY79 original sample. Thus, we can examine the correlation between self-efficacy and indicators of financial preparedness in 
younger, as well as in older adults. In Table 7 we use two indicators of financial preparedness: having emergency funds saved up, and having health insurance, which are data items available for the NLSY79CYA sample of younger adults. We find that increasing the self-efficacy percentile from $0 \%$ to $100 \%$ corresponds to a $7.59 \%$ increase in the probability that people have emergency funds available and a $6.13 \%$ decreased in the probability that they do not have health insurance ( $p<0.01$ for both estimates). The negative effect of self-efficacy on the likelihood of being uninsured continues to be large and significant $(-5.18 \%, p<0.05)$ even after we control for whether health insurance is offered to the individual through their job. This controls for possible effects of self-efficacy on a person' choice of job type, and thus allows us to isolate the effect of self-efficacy on the decision to get health insurance, rather on the availability of insurance. In Table 8 we use three indicators of financial preparedness available in the NLSY79 sample of older adults: having set aside emergency funds, having already engaged in activities to help with financial aspects of retirement planning, and having long-term care insurance. We find that an increase in the self-efficacy percentile from $0 \%$ to $100 \%$ corresponds to an increase of $12.02 \%(p<0.01)$ in the probability of having emergency funds, an increase of $8.45 \%(p<0.01)$ in the probability of retirement planning activities, and 3.01\% $(p<0.1)$ in the probability of having long-term care insurance. Thus, across younger and older adults, we document that self-efficacy earlier in life can help predict the degree to which people have worked to prepare themselves to deal with potential adverse financial shocks later on.

This result suggests that we should observe, as implied by our theoretical setting, that people with higher self-efficacy will be better able to weather negative financial events. The evidence in Table 9 supports this implication. There, we consider two indicators of negative financial shocks: whether the person has lost their job in the past year, and whether they have incurred a health shock leading to significant medical expenses. In the regression models in the first and fourth columns in the table, we document that self-efficacy is not related to the probability of either of these two types of shocks occurring. However, as the 
results in the other regressions in the table show, the likelihood of financial delinquency following such a shock is significantly smaller for people with higher self-efficacy. In columns two and three we examine the role of the job loss indicator and its interaction with the person's self-efficacy on the probability that the individual is late making debt payments, and paying their bills, respectively. In columns five and six we examine the role of the health shock indicator and its interaction with the person's self-efficacy on the same two indicators of financial delinquency - namely, being late making debt payments, and paying bills. Across these four specifications we find that the shock itself, either job loss or health issue, increases the probability of financial delinquency significantly, by $4.86 \%$ to $13.28 \%$ $(p<0.01)$, a finding consistent with prior studies that have shown that job loss and large medical expenditures increase default (Elul et al. (2010), Gross and Notowidigdo (2011), Hsu et al. (2014)). Moreover, self-efficacy continues to be a negative predictor of delinquency, in line with all our results so far.

The novel finding in these models is the negative effect on the likelihood of delinquency of the interaction term between the financial shock indicator and self-efficacy. Across these regression models, comparing the coefficient on the financial shock indicator and on the interaction term between the financial shock indicator and the person's self-efficacy shows that negative financial shocks increase the probability of financial delinquency significantly only among people with low self-efficacy. Specifically, increasing the self-efficacy percentile from $0 \%$ to $100 \%$ leads to a drop of $13.14 \%(p<0.01)$ and $13.35 \%(p<0.05)$, respectively, in the likelihood of being late paying debt and that of being late paying bills, if a job loss occurs, which implies that among the highest self-efficacy people job loss has negligible effects on financial delinquency. Similarly, we find that increasing the self-efficacy percentile from $0 \%$ to $100 \%$ lowers the probability of being late paying bills by $7.46 \%(p<0.01))$ in the event that a health shock occurs, almost completely mitigating the $8.40 \%$ increase in this type of delinquency caused by the health shock itself. Thus, these results show that high self-efficacy can significantly lessen the impact of a job loss or of an adverse health event on 
the individual's propensity to become financially delinquent.

\section{Discussion}

Our analysis provides evidence that self-efficacy may be an important determinant of household financial distress. It is important to emphasize that our findings are not subject to a concern about reverse causality. If self-efficacy and distress were measured contemporaneously, one might worry that respondents express having less control over their lives because they have recently defaulted on debt. For this reason we take advantage of the longitudinal structure of the NLSY and use the self-efficacy measure obtained years before the financial outcomes are realized. As a result, the negative correlation that we document does not represent the effect of past financial default on self-efficacy.

In light of prior evidence that self-efficacy and other non-cognitive abilities have important effects on behavior, omitted variables bias is certainly possible. We control for a number of important observable differences such as income, educational attainment, or parental inputs, but there are nevertheless unobserved variables such as financial wealth and expectations for income growth and uncertainty that may also explain delinquency decisions. A related concern is that our control variables suffer from measurement error, and that self-efficacy proxies for unmeasured ability.

Our self-efficacy measure may also contain aspects of general optimism as measured in Puri and Robinson (2007), but there are important differences between the two. General optimism differs from self-efficacy, in that it does not specifically measure the subjective impact of agency, that is, the perception of the impact of one's effort, on the likelihood of obtaining a good future outcome. Rather, increased optimism refers to a shift upward in the distribution of outcomes people believe are possible. Therefore, optimism and self-efficacy have different implications for the level of effort exerted by people to attain good outcomes.

Individuals with high levels of optimism will not work very hard, since they expect the good 
outcome to happen anyway, and this implies that excessive optimism is detrimental, a finding documented by Puri and Robinson (2007). Individuals with high self-efficacy, on the other hand, will expend high levels of effort to try to accomplish a good outcome, because of their perceived high return to effort. In our data, we indeed find no detrimental effect of having the highest levels of self-efficacy. On the contrary, as can be seen in Figure 1, individuals with the highest self efficacy are those with the lowest rates of financial distress.

\section{Conclusion}

Recent work in economics and psychology has emphasized the importance of non-cognitive abilities in educational and job market success. Here, we find that non-cognitive skills also play an important role in determining financial success. More specifically, we find that selfefficacy predicts substantial differences in financial distress later in life. Individuals who believe more strongly that they can change future outcomes though their actions, are less likely, years later, to be delinquent on loans, and to suffer consequences such as having assets repossessed or property foreclosed, or to lose access to traditional credit. We also document that those with higher self efficacy prepare more to avoid financial distress later in life, and have a lower probability of being financially delinquent upon facing negative financial shocks induced by a job loss or a health event.

Identifying the role of non-cognitive abilities such as self-efficacy on household financial outcomes is useful because, unlike other characteristics that may be pre-determined, noncognitive skills can be improved via interventions at various stages in life. For example, Heckman et al. (2013) show that an intervention in early childhood, the Perry Preschool program, improved participants schooling and labor market outcomes mainly through an increase in non-cognitive skills. It is therefore possible that by helping people believe more in their own capacity to influence the future, they will in fact take action and achieve better financial outcomes. We believe this is a fruitful avenue for future work in household finance. 


\section{References}

Agarwal, S. and Mazumder, B.: 2013, Cognitive abilities and household financial decision making, American Economic Journal: Applied Economics 5(1), 193-207.

Bandura, A.: 1986, Social foundations of thought and action: A social cognitive theory, Englewood Cliffs, NJ: Prentice-Hall.

Cadena, B. C. and Keys, B. J.: 2013, Can self-control explain avoiding free money? Evidence from interest-free student loans, Review of Economics and Statistics 95(4), 1117-1129.

Cadena, B. C. and Keys, B. J.: 2015, Human capital and the lifetime costs of impatience, American Economic Journal: Economic Policy 7(3), 126-153.

Campbell, J. Y.: 2006, Household finance, Journal of Finance 61, 1553-1604.

Campbell, J. Y. and Cocco, J. F.: 2015, A model of mortgage default, Journal of Finance 70(4), $1495-1554$.

Caputo, R. K.: 2012, Patterns and predictors of debt: A panel study, 1985-2008, Journal of Sociology and Social Welfare 39(2), 7-29.

Chatterjee, S., Corbae, D., Nakajima, M. and Rios-Rull, J.-V.: 2007, A quantitative theory of unsecured consumer credit with risk of default, Econometrica 75(6), 1525-1589.

Choi, J. J., Laibson, D. and Madrian, B. C.: 2010, Why does the law of one price fail? An experiment on index mutual funds, Review of Financial Studies 23(4), 1405-1432.

Cole, S., Paulson, A. and Shastry, G. K.: 2012, Smart money: The effect of education on financial behavior, Harvard Business School Working Paper No. 09-071 .

DellaVigna, S. and Paserman, M. D.: 2005, Job search and impatience, Journal of Labor Economics 23(3). 
Deng, Y., Quigley, J. M. and Van Order, R.: 2000, Mortgage terminations, heterogeneity and the exercise of mortgage options, Econometrica 68(2), 275-307.

Elul, R., Souleles, N., Chomsisengphet, S., Glennon, D. and Hunt, R.: 2010, What "triggers" mortgage default?, American Economic Review Papers and Proceedings 100, 490-494.

Fay, S., Hurst, E. and White, M. J.: 2002, The household bankruptcy decision, American Economic Review 92(3), 706-718.

Foote, C., Gerardi, K. and Willen, P.: 2008, Negative equity and foreclosure: Theory and evidence, Journal of Urban Economics 6(2), 234-245.

Gerardi, K., Goette, L. and Meier, S.: 2013, Numerical ability predicts mortgage default, Proceedings of the National Academy of Sciences 110(28), 11267-11271.

Greenwood, R. and Shleifer, A.: 2014, Expectations of returns and expected returns, Review of Financial Studies 27(3), 714-746.

Grinblatt, M., Keloharju, M. and Linnainmaa, J.: 2011, Iq and stock market participation, Journal of Finance 66(6), 2119-2164.

Gross, T. and Notowidigdo, M. J.: 2011, Health insurance and the consumer bankruptcy decision: Evidence from expansions of medicaid, Journal of Public Economics 95(7-8), 767778 .

Guiso, L., Sapienza, P. and Zingales, L.: 2013, The determinants of attitudes toward strategic default on mortgages, The Journal of Finance 68, 1473-1515.

Heckman, J. J., Pinto, R. and Savelyev, P.: 2013, Understanding the mechanisms through which an influential early childhood program boosted adult outcomes, American Economic Review 103(6), 2052-2086. 
Heckman, J. J., Sixrud, J. and Urzua, S.: 2006, The effects of cognitive and non-cognitive abilities on labor market outcomes and social behavior, Journal of Labor Economics 24(3), 411-482.

Hsu, J., Melzer, B. T. and Matsa, D. A.: 2014, Positive externalities of social insurance: Unemployment insurance and consumer credit, NBER Working Paper w20353.

Judge, T. A. and Bono, J. E.: 2001, Relationship of core self-evaluations traits - self-esteem, generalized self-efficacy, locus of control and emotional stability - with job satisfaction and job performance: A meta-analysis, Journal of Applied Psychology 86, 80-92.

Kalil, A. and Khalid, S.: 2010, Non-cognitive skills and educational attainment, Working paper.

Kezdi, G. and Willis, R. J.: 2011, Household stock market beliefs and learning, NBER Working Paper No. 17614.

Kuchler, T. and Zafar, B.: 2016, Personal experiences and expectations about aggregate outcomes, Working paper.

Kuhnen, C. M. and Miu, A. C.: forthcoming, Socioeconomic status and learning from financial information, Journal of Financial Economics .

Lachman, M. E. and Weaver, S. L.: 1998, The sense of control as a moderator of social class differences in health and well-being, Journal of Personality and Social Psychology 74, 763-773.

Lindqvist, E. and Vestman, R.: 2011, The labor market returns to cognitive and noncognitive ability: Evidence from the Swedish enlistment, American Economic Journal: Applied Economics 3(1), 101-128.

Lusardi, A.-M. and Mitchell, O.: 2009, How ordinary consumers make complex economic 
decisions: Financial literacy and retirement readiness, National Bureau of Economic Research Working Paper No. 15350. .

Malmendier, U. and Nagel, S.: 2016, Learning from inflation experiences, Quarterly Journal of Economics 131(1), 53-87.

Pearlin, L. I., Menaghan, E. G., Lieberman, M. A. and Mullan, J. T.: 1981, The stress process, Journal of Health and Social Behavior 22(4), 337-356.

Pudrovska, T., Schieman, S., Pearlin, L. I. and Nguyen, K.: 2005, The sense of mastery as a mediator and moderator in the association between economic hardship and health in late life, Journal of Aging and Health 17(5), 634-660.

Puri, M. and Robinson, D. T.: 2007, Optimism and economic choice, Journal of Financial Economics 86(1), 71-99.

Rotter, J. B.: 1966, Generalized expectancies for internal versus external control of reinforcement, Psychological Monographs: General and Applied 80(1), 1-28.

Ru, H. and Schoar, A.: 2016, Do credit card companies screen for behavioral biases?, NBER Working Paper 22360.

Shapiro, J. and Wu, S.: 2011, Fatalism and savings, Journal of Socio-Economics 40, 645-651.

Stango, V. and Zinman, J.: 2009, Exponential growth bias and household finance, Journal of Finance 64(6), 2807-2849.

Taylor, S. E. and Seeman, T. E.: 2000, Socioeconomic status and health in industrial nations: Social, psychological, and biological pathways, New York: New York Academy of Sciences, chapter Psychosocial resources and the SES-health relationship, pp. 210-225. 


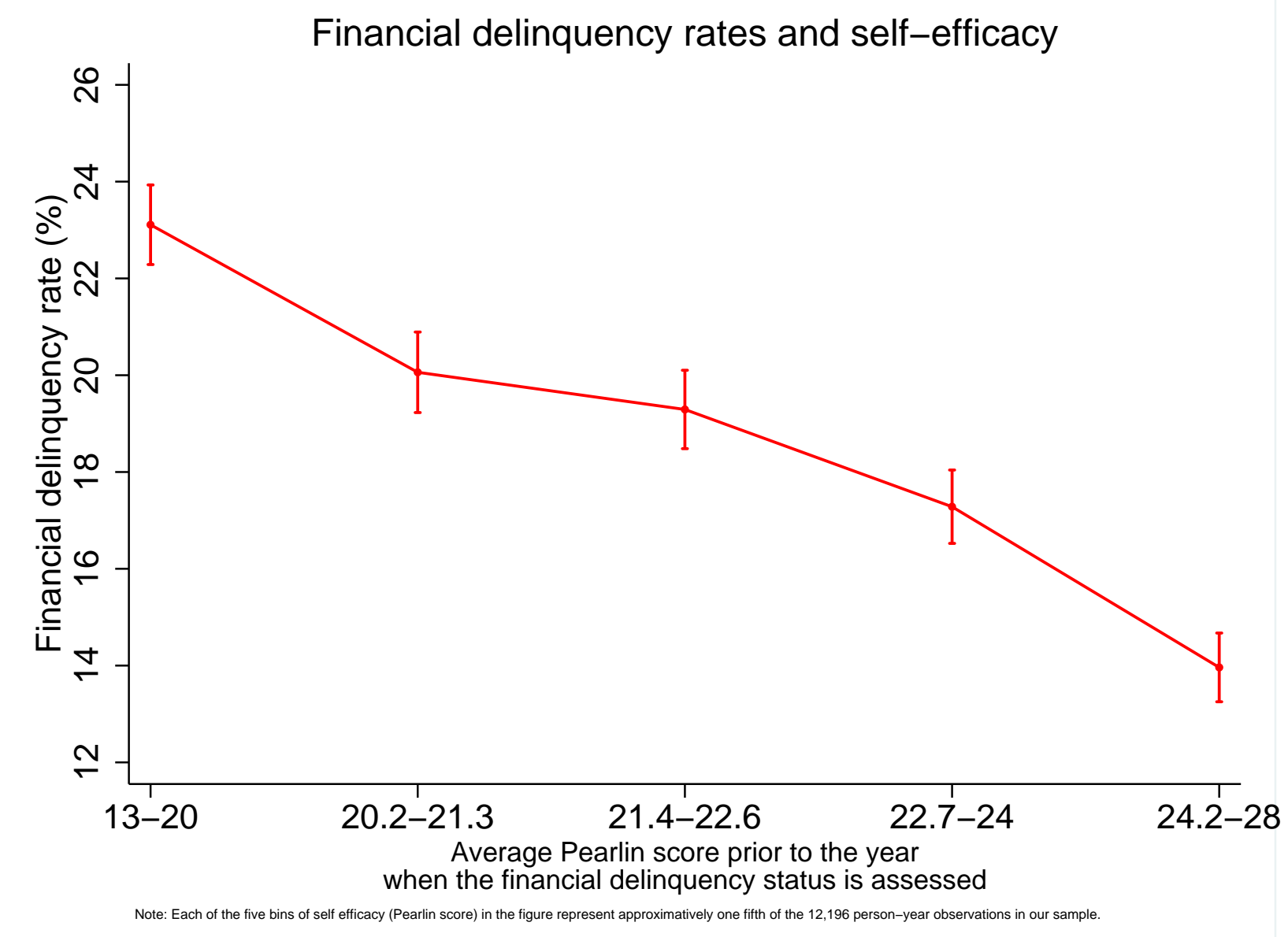

Figure 1: The incidence of financial delinquency in a given survey year, as a function of the self-efficacy of respondents measured earlier in life. The figure shows the average delinquency rates, as well as standard error bars, for each of five categories of Pearlin scores, each containing approximatively one fifth of the 12,196 person-year observations in our sample. Financial delinquency is defined based on whether the respondent indicated being late paying their debt, or paying their bills. For $18.81 \%$ of our observations, the respondent is classified as being financially delinquent. 
Table 1: Summary statistics.

The person-year observations summarized below refer to 6031 unique individuals in years 2010, 2012, and 2014, when questions regarding financial variables are asked of the participants in the National Longitudinal Survey Youth 1979 Child and Young Adult sample.

\begin{tabular}{|c|c|c|c|}
\hline Variable & Mean & St. Dev. & $\mathrm{N}$ \\
\hline Self-Efficacy ${ }_{i}$ (Pearlin percentile score) & 0.51 & 0.29 & $\overline{12,196}$ \\
\hline$A_{g e}{ }_{i t}$ (years) & 27.03 & 4.20 & 12,196 \\
\hline Cognitive ability $_{i}$ (normalized) & -0.09 & 0.99 & 12,196 \\
\hline Risk aversion (normalized) $^{-}$ & -0.02 & 0.98 & 12,196 \\
\hline Patience $_{i}$ & 2.43 & 0.44 & 12,196 \\
\hline Income $(\log )_{i t}$ & 8.78 & 3.46 & 12,196 \\
\hline Late debt ${ }_{i t}$ & & Yes: $11.35 \%$ & 11,892 \\
\hline Late bills & & Yes: $12.50 \%$ & 11,878 \\
\hline Accounts in Collection $_{i t}$ & & Yes: $18.20 \%$ & 12,151 \\
\hline Foreclosure, Repossession, or Bankruptcy ${ }_{i t}$ & & Yes: $3.15 \%$ & 12,187 \\
\hline Credit Card $_{i t}$ & & Yes: $41.89 \%$ & 12,191 \\
\hline Vehicle loan $i t$ & & Yes: $30.93 \%$ & 12,087 \\
\hline Mortgage $_{i t}$ & & Yes: $15.21 \%$ & 12,196 \\
\hline Payday loan $i t$ & & Yes: $5.86 \%$ & 12,180 \\
\hline Emergency funds $s_{i t}$ & & Yes: $3.67 \%$ & 8,423 \\
\hline No health insurance ${ }_{i t}$ & & Yes: $34.28 \%$ & 12,196 \\
\hline
\end{tabular}

\begin{tabular}{lrr}
\hline Education & No high school: $17.25 \%$ & 12,196 \\
& High school: $55.26 \%$ & 12,196 \\
Some college: $8.53 \%$ & 12,196 \\
College: $15.49 \%$ & 12,196 \\
& Graduate degree: $3.47 \%$ & 12,196 \\
\hline Gender & $48 \%$ men, $52 \%$ women & 12,196 \\
\hline Race & $21.85 \%$ hispanic & 12,196 \\
& $34.90 \%$ black & 12,196 \\
& $43.25 \%$ non-black, non-hispanic & 12,196 \\
\hline
\end{tabular}


Table 2: Self-efficacy and financial delinquency. Linear probability models, with standard errors clustered by participant. Probit models yield similar results. Self-efficacyi refers to person $i$ 's percentile in the distribution of Pearlin scores. Education omitted category: Graduate degree $_{i}$. T-statistics are shown in parentheses. ${ }^{* * *},{ }^{* *}$ and ${ }^{*}$ indicate significance at the $1 \%, 5 \%$ and $10 \%$ level, respectively.

\begin{tabular}{|c|c|c|c|c|c|c|}
\hline $\begin{array}{l}\text { Dependent } \\
\text { variable }\end{array}$ & $\begin{array}{l}\text { Late } \\
\text { debt }_{i t}\end{array}$ & $\begin{array}{l}\text { Late } \\
\text { debt }{ }_{i t}\end{array}$ & $\begin{array}{l}\text { Late } \\
\text { debt }{ }_{i t}\end{array}$ & $\begin{array}{c}\text { Late } \\
\text { bills }_{i t}\end{array}$ & $\begin{array}{l}\text { Late } \\
\text { bills }_{i t}\end{array}$ & $\begin{array}{l}\text { Late } \\
\text { bills }_{i t}\end{array}$ \\
\hline \multirow[t]{2}{*}{ Self-efficacy } & -4.68 & -5.01 & -5.56 & -9.55 & $\begin{array}{c}-7.26 \\
\end{array}$ & -5.28 \\
\hline & $(-4.16)^{* * *}$ & $(-4.21)^{* * *}$ & $(-4.65)^{* * *}$ & $(-8.21)^{* * *}$ & $(-6.09)^{* * * *}$ & $(-4.43)^{* * *}$ \\
\hline \multirow[t]{2}{*}{$A g e_{i t}$} & & 0.25 & 0.21 & & 0.68 & 0.76 \\
\hline & & $(3.35)^{* * *}$ & $(2.68)^{* * *}$ & & $(8.19)^{* * *}$ & $(8.89)^{* * *}$ \\
\hline \multirow{2}{*}{ Cognitive ability $_{i}$} & & 0.92 & 0.93 & & -1.85 & -0.29 \\
\hline & & $(2.45)^{* *}$ & $(2.22)^{* *}$ & & $(-4.83)^{* * *}$ & $(-0.70)$ \\
\hline \multirow[t]{2}{*}{ Risk aversion $_{i}$} & & -0.78 & -0.70 & & -1.31 & -1.22 \\
\hline & & $(-2.11)^{* *}$ & $(-1.93)^{*}$ & & $(-3.54)^{* * *}$ & $(-3.30)^{* * *}$ \\
\hline \multirow[t]{2}{*}{ Patience $_{i}$} & & -2.70 & -2.91 & & -4.21 & -3.25 \\
\hline & & $(-3.47)^{* * *}$ & $(-3.74)^{* * *}$ & & $(-5.46)^{* * *}$ & $(-4.22)^{* * *}$ \\
\hline \multirow[t]{2}{*}{ No highschool $_{i}$} & & & 7.04 & & & 11.79 \\
\hline & & & $(4.11)^{* * *}$ & & & $(7.07)^{* * *}$ \\
\hline \multirow[t]{2}{*}{ Highschool $_{i}$} & & & 7.80 & & & 8.41 \\
\hline & & & $(5.27)^{* * *}$ & & & $(6.34)^{* * *}$ \\
\hline \multirow[t]{2}{*}{ Some college $_{i}$} & & & 5.00 & & & 4.68 \\
\hline & & & $(2.96)^{* * *}$ & & & $(2.95)^{* * *}$ \\
\hline \multirow{2}{*}{ College $_{i}$} & & & 2.36 & & & 1.88 \\
\hline & & & $(1.62)$ & & & $(1.51)$ \\
\hline \multirow[t]{2}{*}{$\operatorname{Income}(\log )_{i t}$} & & & 0.02 & & & -0.40 \\
\hline & & & $(0.20)$ & & & $(-3.59)^{* * *}$ \\
\hline \multirow{2}{*}{ Has Debt ${ }_{i t}$} & & & 8.13 & & & \\
\hline & & & $(10.90)^{* * *}$ & & & \\
\hline Gender FEs & No & Yes & Yes & Yes & Yes & Yes \\
\hline Race FEs & No & Yes & Yes & Yes & Yes & Yes \\
\hline$R^{2}$ & 0.002 & 0.01 & 0.03 & 0.01 & 0.03 & 0.04 \\
\hline Observations & 11892 & 11892 & 11892 & 11878 & 11878 & 11878 \\
\hline
\end{tabular}


Table 3: Self-efficacy and asset-related consequences of financial delinquency. Linear probability models, with standard errors clustered by participant. Probit models yield similar results. Self-efficacy $i$ refers to person $i$ 's percentile in the distribution of Pearlin scores. Education omitted category: Graduate degree $_{i}$. T-statistics are shown in parentheses. ${ }^{* * *}$, ** and ${ }^{*}$ indicate significance at the $1 \%, 5 \%$ and $10 \%$ level, respectively.

\begin{tabular}{|c|c|c|c|c|c|c|}
\hline \multirow{2}{*}{$\begin{array}{l}\text { Dependent } \\
\text { variable } \\
\text { Self-efficacy } y_{i}\end{array}$} & \multicolumn{3}{|c|}{$\begin{array}{l}\text { Accounts in } \\
\text { Collection }_{i t}\end{array}$} & \multicolumn{3}{|c|}{$\begin{array}{c}\text { Foreclosure, Repossession } \\
\text { orBankruptcy }\end{array}$} \\
\hline & -4.68 & -4.20 & -2.84 & -1.98 & -1.72 & -1.54 \\
\hline & $(-3.30)^{* * *}$ & $(-2.82)^{* * *}$ & $(-1.90)^{*}$ & $(-3.22)^{* * *}$ & $(-2.74)^{* * *}$ & $(-2.41)^{* *}$ \\
\hline \multirow[t]{2}{*}{$A g e_{i t}$} & & 0.51 & 0.54 & & 0.27 & 0.27 \\
\hline & & $(5.48)^{* * *}$ & $(5.66)^{* * *}$ & & $(6.29)^{* * *}$ & $(6.04)^{* * *}$ \\
\hline \multirow[t]{2}{*}{ Cognitive ability $_{i}$} & & 0.92 & 2.66 & & -0.32 & -0.04 \\
\hline & & $(1.90)^{*}$ & $(5.16)^{* * *}$ & & $(-1.63)$ & $(-0.18)$ \\
\hline \multirow{2}{*}{ Risk aversion $_{i}$} & & -1.09 & -0.79 & & -0.20 & -0.14 \\
\hline & & $(-2.37)^{* *}$ & $(-1.74)^{*}$ & & $(-1.01)$ & $(-0.72)$ \\
\hline \multirow[t]{2}{*}{ Patience $_{i}$} & & -6.89 & -5.95 & & -0.38 & -0.24 \\
\hline & & $(-6.83)^{* * *}$ & $(-5.91)^{* * *}$ & & $(-0.96)$ & $(-0.58)$ \\
\hline \multirow[t]{2}{*}{ No highschool $i$} & & & 14.98 & & & 2.62 \\
\hline & & & $(6.99)^{* * *}$ & & & $(2.71)^{* * *}$ \\
\hline \multirow[t]{2}{*}{ Highschool $_{i}$} & & & 13.52 & & & 2.27 \\
\hline & & & $(7.49)^{* * *}$ & & & $(2.78)^{* * *}$ \\
\hline \multirow[t]{2}{*}{ Some college $_{i}$} & & & 7.64 & & & 1.08 \\
\hline & & & $(3.65)^{* * *}$ & & & $(1.18)$ \\
\hline \multirow[t]{2}{*}{ College $_{i}$} & & & 0.71 & & & -0.01 \\
\hline & & & $(0.41)$ & & & $(-0.01)$ \\
\hline \multirow[t]{2}{*}{ Income $(\log )_{i t}$} & & & 0.41 & & & 0.13 \\
\hline & & & $(3.63)^{* * *}$ & & & $(2.77)^{* * *}$ \\
\hline Gender FEs & No & Yes & Yes & Yes & Yes & Yes \\
\hline Race FEs & No & Yes & Yes & Yes & Yes & Yes \\
\hline$R^{2}$ & 0.001 & 0.02 & 0.04 & 0.001 & 0.01 & 0.01 \\
\hline Observations & 12151 & 12151 & 12151 & 12187 & 12187 & 12187 \\
\hline
\end{tabular}


Table 4: Self-efficacy and credit-related consequences of delinquency. Data are from the NLSY79 original cohort in the first two columns, and from the NLSY97CYA in the last four columns. Linear probability models, with standard errors clustered by participant. Probit

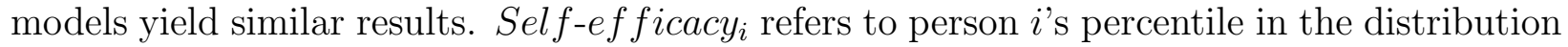
of Pearlin scores. Education omitted category: Graduate degree ${ }_{i}$. T-statistics are shown in parentheses. ${ }^{* * *},{ }^{* *}$ and ${ }^{*}$ indicate significance at the $1 \%, 5 \%$ and $10 \%$ level, respectively.

\begin{tabular}{|c|c|c|c|c|c|c|}
\hline $\begin{array}{l}\text { Dependent } \\
\text { variable }\end{array}$ & $\begin{array}{c}\text { Applied } \\
\text { for }_{\text {credit }} \text { it }\end{array}$ & $\begin{array}{l}\text { Applied\& } \\
\text { rejected }_{i t}\end{array}$ & $\begin{array}{l}\text { Credit } \\
\text { card }_{i t}\end{array}$ & $\begin{array}{c}\text { Vehicle } \\
\text { loan }_{i t}\end{array}$ & $\begin{array}{l}\text { Mort- } \\
\text { gage }_{i t}\end{array}$ & $\begin{array}{l}\text { Payday } \\
\text { loan }_{i t}\end{array}$ \\
\hline \multirow[t]{2}{*}{ Self-efficacy } & 1.33 & -10.18 & 3.76 & 5.24 & 4.95 & -2.90 \\
\hline & $(0.58)$ & $(-3.05)^{* * *}$ & $(2.15)^{* *}$ & $(3.17)^{* * *}$ & $(3.76)^{* * *}$ & $(-3.31)^{* * *}$ \\
\hline \multirow[t]{2}{*}{$A g e_{i t}$} & -0.35 & -1.12 & 0.34 & 0.89 & 2.03 & 0.25 \\
\hline & $(-1.23)$ & $(-2.75)^{* * *}$ & $(3.21)^{* * *}$ & $(8.88)^{* * *}$ & $(23.06)^{* * *}$ & $(4.21)^{* * *}$ \\
\hline \multirow[t]{2}{*}{ Cognitive ability $_{i}$} & 0.32 & 0.02 & 6.05 & 0.62 & -0.43 & 0.35 \\
\hline & $(9.93)^{* * *}$ & $(0.46)$ & $(10.06)^{* * *}$ & $(1.09)$ & $(-0.93)$ & $(1.16)$ \\
\hline \multirow[t]{2}{*}{ Risk aversion $_{i}$} & 0.43 & 0.50 & 0.53 & 0.97 & 0.57 & -0.15 \\
\hline & $(1.95)^{*}$ & $(1.32)$ & $(1.02)$ & $(1.99)^{* *}$ & (1.43) & $(-0.54)$ \\
\hline \multirow[t]{2}{*}{ Patience $_{i}$} & -0.61 & 0.14 & 4.26 & 0.74 & 1.42 & -1.61 \\
\hline & $(-0.31)$ & $(0.04)$ & $(3.78)^{* * *}$ & $(0.69)$ & $(1.59)$ & $(-2.69)^{* * *}$ \\
\hline \multirow[t]{2}{*}{ No highschool $_{i}$} & -7.41 & 11.22 & -45.47 & -5.96 & -12.91 & 5.26 \\
\hline & $(-2.40)^{* *}$ & $(2.09)^{* *}$ & $(-18.35)^{* * *}$ & $(-2.07)^{* *}$ & $(-4.74)^{* * *}$ & $(4.59)^{* * *}$ \\
\hline \multirow[t]{2}{*}{ Highschool $_{i}$} & 0.05 & 7.82 & -32.11 & 1.70 & -9.41 & 4.49 \\
\hline & $(0.02)$ & $(2.72)^{* * *}$ & $(-14.17)^{* * *}$ & $(0.62)$ & $(-3.56)^{* * *}$ & $(4.88)^{* * *}$ \\
\hline \multirow[t]{2}{*}{ Some college $_{i}$} & 2.96 & 3.03 & -16.50 & 10.15 & -3.19 & 3.45 \\
\hline & $(0.99)$ & $(0.89)$ & $(-6.20)^{* * *}$ & $(3.30)^{* * *}$ & $(-1.08)$ & $(3.03)^{* * *}$ \\
\hline \multirow[t]{2}{*}{ College $_{i}$} & -2.04 & 0.14 & -5.13 & 1.89 & -1.95 & 1.21 \\
\hline & $(-0.75)$ & $(0.05)$ & $(-2.27)^{* *}$ & $(0.67)$ & $(-0.71)$ & $(1.39)$ \\
\hline \multirow[t]{2}{*}{ Income $(\log )_{i t}$} & 3.65 & -4.41 & 2.40 & 4.03 & 1.53 & 0.47 \\
\hline & $(13.10)^{* * *}$ & $(-4.55)^{* * *}$ & $(20.48)^{* * *}$ & $(51.31)^{* * *}$ & $(18.15)^{* * *}$ & $(7.46)^{* * *}$ \\
\hline Gender FEs & Yes & Yes & Yes & Yes & Yes & Yes \\
\hline Race FEs & Yes & Yes & Yes & Yes & Yes & Yes \\
\hline$R^{2}$ & 0.12 & 0.09 & 0.24 & 0.15 & 0.14 & 0.02 \\
\hline Observations & 5561 & 2336 & 12191 & 12087 & 12196 & 12180 \\
\hline
\end{tabular}


Table 5: Self-efficacy and financial delinquency: parental investment as a mechanism. Linear probability models, with standard errors clustered by participant. Probit models yield similar results. Self-efficacy $y_{i}$ refers to person $i$ 's percentile in the distribution of Pearlin scores. The controls omitted here for brevity are the same as those in the full specifications in Tables 2 through 4 . T-statistics are shown in parentheses. ${ }^{* * *},{ }^{* *}$ and ${ }^{*}$ indicate significance at the $1 \%, 5 \%$ and $10 \%$ level, respectively.

\begin{tabular}{|c|c|c|c|c|c|c|}
\hline $\begin{array}{l}\text { Dependent } \\
\text { variable }\end{array}$ & $\begin{array}{l}\text { Late } \\
\text { debt }_{i t}\end{array}$ & $\begin{array}{l}\text { Late } \\
\text { bills }_{i t}\end{array}$ & $\begin{array}{c}\text { Accounts } \\
\text { in } \\
\text { collection }_{i t}\end{array}$ & $\begin{array}{c}\text { Foreclosure, } \\
\text { Repossession, } \\
\text { or Bankruptcy }\end{array}$ & $\begin{array}{c}\text { Credit card, } \\
\text { Vehicle loan, } \\
\text { or Mortgage } \\
\text { it }\end{array}$ & $\begin{array}{l}\text { Payday } \\
\text { loan }_{i t}\end{array}$ \\
\hline \multirow[t]{2}{*}{ Self-efficacy } & -4.17 & -4.06 & -4.04 & -3.50 & 8.57 & -3.06 \\
\hline & $(-2.42)^{* *}$ & $(-2.17)^{* *}$ & $(-1.98)^{* *}$ & $(-3.65)^{* * *}$ & $(3.60)^{* * *}$ & $(-2.59)^{* * *}$ \\
\hline Controls & Yes & Yes & Yes & Yes & Yes & Yes \\
\hline Mother FEs & Yes & Yes & Yes & Yes & Yes & Yes \\
\hline Gender FEs & Yes & Yes & Yes & Yes & Yes & Yes \\
\hline Race FEs & Yes & Yes & Yes & Yes & Yes & Yes \\
\hline$\overline{R^{2}}$ & 0.09 & 0.10 & 0.17 & 0.04 & 0.38 & 0.12 \\
\hline Observations & 11892 & 11878 & 12151 & 12187 & 12196 & 12180 \\
\hline
\end{tabular}


Table 6: Self-efficacy and financial delinquency: heterogeneous effects based on parental environment. Linear probability models, with standard errors clustered by participant. Probit models yield similar results. Self-ef ficacy refers to person $i$ 's percentile in the distribution of Pearlin scores. The controls omitted here for brevity are the same as those in the full specifications in Tables 2 through 4 . T-statistics are shown in parentheses. ${ }^{* * *},{ }^{* *}$ and ${ }^{*}$ indicate significance at the $1 \%, 5 \%$ and $10 \%$ level, respectively.

\begin{tabular}{|c|c|c|c|c|c|}
\hline $\begin{array}{l}\text { Dependent } \\
\text { variable }\end{array}$ & & & Late de & & \\
\hline & obser & rations & $\begin{array}{r}\text { Lowest tertile } \\
\text { of mother } \\
\text { net worth }\end{array}$ & $\begin{array}{r}\text { Middle tertile } \\
\text { of mother } \\
\text { net worth }\end{array}$ & $\begin{array}{r}\text { Highest tertile } \\
\text { of mother } \\
\text { net worth }\end{array}$ \\
\hline Self-efficacy & $\begin{array}{r}-4.17 \\
(-2.42)^{* *}\end{array}$ & $\begin{array}{r}-5.56 \\
(-4.66)^{* * *}\end{array}$ & $\begin{array}{r}-8.91 \\
(-4.07)^{* * *}\end{array}$ & $\begin{array}{r}-6.35 \\
(-2.96)^{* * *}\end{array}$ & $\begin{array}{r}-3.01 \\
(-1.59)\end{array}$ \\
\hline $\begin{array}{l}\text { Mother net } \\
\text { worth }_{i}(' 000 \mathrm{~s})\end{array}$ & & $\begin{array}{r}-0.01 \\
(-5.51)^{* * *} \\
\end{array}$ & & & \\
\hline Controls & Yes & Yes & Yes & Yes & Yes \\
\hline Mother FEs & Yes & No & No & No & No \\
\hline Gender FEs & Yes & Yes & Yes & Yes & Yes \\
\hline Race FEs & Yes & Yes & Yes & Yes & Yes \\
\hline$R^{2}$ & 0.09 & 0.03 & 0.04 & 0.02 & 0.03 \\
\hline Observations & 11892 & 11891 & 3708 & 4068 & 4115 \\
\hline
\end{tabular}


Table 7: Self-efficacy and financial preparedness early in adulthood. Linear probability models, with standard errors clustered by participant. Probit models yield similar results. Self-efficacy $i$ refers to person $i$ 's percentile in the distribution of Pearlin scores. Education omitted category: Graduate degree ${ }_{i}$. T-statistics are shown in parentheses. ${ }^{* * *},{ }^{* *}$ and ${ }^{*}$ indicate significance at the $1 \%, 5 \%$ and $10 \%$ level, respectively.

\begin{tabular}{|c|c|c|c|}
\hline $\begin{array}{l}\text { Dependent } \\
\text { variable }\end{array}$ & $\begin{array}{l}\text { Emergency } \\
\text { funds } s_{i t}\end{array}$ & $\begin{array}{l}\text { No health } \\
\text { insurance }_{i t}\end{array}$ & $\begin{array}{l}\text { No health } \\
\text { insurance } i t\end{array}$ \\
\hline \multirow{2}{*}{ Self-efficacy } & 7.59 & -6.13 & -5.18 \\
\hline & $(3.68)^{* * *}$ & $(-3.25)^{* * *}$ & $(-2.33)^{* *}$ \\
\hline \multirow[t]{2}{*}{$\mathrm{Age}_{i t}$} & -0.24 & -0.18 & -0.53 \\
\hline & $(-1.94)^{*}$ & $(-1.66)^{*}$ & $(-3.84)^{* * *}$ \\
\hline \multirow{2}{*}{ Cognitive ability $_{i}$} & -1.88 & 0.25 & 0.83 \\
\hline & $(-2.65)^{* * *}$ & $(0.39)$ & $(1.12)$ \\
\hline \multirow[t]{2}{*}{ Risk aversion $_{i}$} & 0.35 & -2.24 & -1.01 \\
\hline & $(0.56)$ & $(-3.99)^{* * *}$ & $(-1.54)$ \\
\hline \multirow[t]{2}{*}{ Patience $_{i}$} & 7.36 & -6.68 & -6.63 \\
\hline & $(5.68)^{* * *}$ & $(-5.47)^{* * *}$ & $(-4.60)^{* * *}$ \\
\hline \multirow[t]{2}{*}{ No highschool $_{i}$} & -32.27 & 25.85 & 22.98 \\
\hline & $(-9.69)^{* * *}$ & $(9.71)^{* * *}$ & $(7.80)^{* * *}$ \\
\hline \multirow{2}{*}{ Highschool $_{i}$} & -25.03 & 13.07 & 8.94 \\
\hline & $(-8.15)^{* * *}$ & $(5.70)^{* * *}$ & $(4.13)^{* * *}$ \\
\hline \multirow[t]{2}{*}{ Some college $_{i}$} & -16.54 & 4.75 & 2.50 \\
\hline & $(-4.74)^{* * *}$ & $(1.83)^{*}$ & $(1.01)$ \\
\hline \multirow{2}{*}{ College $_{i}$} & -7.39 & 0.12 & 0.28 \\
\hline & $(-2.33)^{* *}$ & $(0.05)$ & $(0.13)$ \\
\hline \multirow[t]{2}{*}{ Income $(\log )_{i t}$} & 1.65 & -0.24 & -2.73 \\
\hline & $(11.05)^{* * *}$ & $(-1.60)$ & $(-9.11)^{* * *}$ \\
\hline Health insurance & & & -12.77 \\
\hline of fered by employer & & & $(-6.03)^{* * *}$ \\
\hline Gender FEs & Yes & Yes & Yes \\
\hline Race FEs & Yes & Yes & Yes \\
\hline$R^{2}$ & 0.07 & 0.06 & 0.08 \\
\hline Observations & 8423 & 12196 & 6725 \\
\hline
\end{tabular}


Table 8: Self-efficacy and financial preparedness late in adulthood. Data come from the NLSY79 original sample. Linear probability models, with standard errors clustered by participant. Probit models yield similar results. Self-efficacy refers to person $i$ 's percentile in the distribution of Pearlin scores. Education omitted category: Graduate degree $e_{i}$. Tstatistics are shown in parentheses. ${ }^{* * *},{ }^{* *}$ and ${ }^{*}$ indicate significance at the $1 \%, 5 \%$ and $10 \%$ level, respectively.

\begin{tabular}{|c|c|c|c|}
\hline $\begin{array}{l}\text { Dependent } \\
\text { variable } \\
\end{array}$ & $\begin{array}{c}\text { Emergency } \\
\text { funds }_{i t}\end{array}$ & $\begin{array}{c}\text { Retirement }_{\text {planning }} \text { it } \\
\end{array}$ & $\begin{array}{c}\text { Long-term care } \\
\text { insurance }_{i t}\end{array}$ \\
\hline \multirow[t]{2}{*}{ Self-efficacy } & 12.02 & 8.45 & 3.01 \\
\hline & $(5.37)^{* * *}$ & $(3.65)^{* * *}$ & $(1.92)^{*}$ \\
\hline \multirow[t]{2}{*}{$A g e_{i t}$} & 0.65 & 0.71 & 0.36 \\
\hline & $(2.35)^{* *}$ & $(2.57)^{* *}$ & $(1.93)^{*}$ \\
\hline \multirow[t]{2}{*}{ Cognitive ability $_{i}$} & 0.14 & 0.23 & -0.02 \\
\hline & $(4.40)^{* * *}$ & $(7.45)^{* * *}$ & $(-1.10)$ \\
\hline \multirow[t]{2}{*}{ Risk aversion $_{i}$} & 0.88 & 1.10 & -0.12 \\
\hline & $(4.03)^{* * *}$ & $(4.80)^{* * *}$ & $(-0.80)$ \\
\hline \multirow{2}{*}{ Patience $_{i}$} & -1.85 & 0.75 & -1.88 \\
\hline & $(-0.97)$ & $(0.38)$ & $(-1.51)$ \\
\hline \multirow[t]{2}{*}{ No highschool $_{i}$} & -18.54 & -22.78 & -9.35 \\
\hline & $(-6.17)^{* * *}$ & $(-7.60)^{* * *}$ & $(-4.36)^{* * *}$ \\
\hline \multirow[t]{2}{*}{ Highschool $_{i}$} & -13.74 & -14.16 & -6.22 \\
\hline & $(-5.58)^{* * *}$ & $(-6.22)^{* * *}$ & $(-3.31)^{* * *}$ \\
\hline \multirow[t]{2}{*}{ Some college $_{i}$} & -7.94 & -4.06 & -4.32 \\
\hline & $(-2.71)^{* * *}$ & $(-1.50)$ & $(-1.99)^{* *}$ \\
\hline \multirow[t]{2}{*}{ College $_{i}$} & 1.61 & -3.63 & -5.34 \\
\hline & $(0.61)$ & $(-1.56)$ & $(-2.66)^{* * *}$ \\
\hline \multirow{2}{*}{ Income $(\log )_{i t}$} & 3.84 & 2.70 & 1.07 \\
\hline & $(12.46)^{* * *}$ & $(8.44)^{* * *}$ & $(5.82)^{* * *}$ \\
\hline \multirow[t]{2}{*}{ Net worth ('000s) $^{\prime}$} & & 0.04 & 0.01 \\
\hline & & $(13.44)^{* * *}$ & $(3.84)^{* * *}$ \\
\hline Gender FEs & Yes & Yes & Yes \\
\hline Race FEs & Yes & Yes & Yes \\
\hline$\overline{R^{2}}$ & 0.13 & 0.19 & 0.02 \\
\hline Observations & 5565 & 5445 & 5466 \\
\hline
\end{tabular}


Table 9: Self-efficacy and dealing with financial shocks. Linear probability models, with standard errors clustered by participant. Probit models yield similar results. Self-efficacyi refers to person $i$ 's percentile in the distribution of Pearlin scores. The controls omitted here for brevity are the same as those in the full specifications in Table 2. T-statistics are shown in parentheses. ${ }^{* * *},{ }^{* *}$ and ${ }^{*}$ indicate significance at the $1 \%, 5 \%$ and $10 \%$ level, respectively.

\begin{tabular}{|c|c|c|c|c|c|c|}
\hline $\begin{array}{l}\text { Dependent } \\
\text { variable }\end{array}$ & $\begin{array}{l}\text { Lost } \\
\text { job }_{i t}\end{array}$ & $\begin{array}{l}\text { Late } \\
\text { debt }_{\text {it }}\end{array}$ & $\begin{array}{c}\text { Late } \\
\text { bills }_{i t}\end{array}$ & $\begin{array}{l}\text { Health } \\
\text { shock }_{i t}\end{array}$ & $\begin{array}{l}\text { Late } \\
\text { debt }_{i t}\end{array}$ & $\begin{array}{l}\text { Late } \\
\text { bills }_{i t}\end{array}$ \\
\hline \multirow[t]{2}{*}{ Self-efficacy } & -0.00 & -5.05 & -4.34 & 0.00 & -4.96 & -3.24 \\
\hline & $(-0.37)$ & $(-3.96)^{* * *}$ & $(-3.48)^{* * *}$ & $(0.30)$ & $(-3.72)^{* * *}$ & $(-2.46)^{* *}$ \\
\hline \multirow[t]{2}{*}{ Lost job } & & 13.28 & 10.91 & & & \\
\hline & & $(4.18)^{* * *}$ & $(3.32)^{* * *}$ & & & \\
\hline Lost job & & -13.14 & -13.35 & & & \\
\hline$X$ Self-efficacy $y_{i}$ & & $(-2.61)^{* * *}$ & $(-2.51)^{* *}$ & & & \\
\hline \multirow[t]{2}{*}{ Health shock } & & & & & 4.86 & 8.40 \\
\hline & & & & & $(3.21)^{* * *}$ & $(5.10)^{* * *}$ \\
\hline Health shock & & & & & -2.24 & -7.46 \\
\hline$X$ Self-efficacy & & & & & $(-0.93)$ & $(-2.92)^{* * *}$ \\
\hline Controls & Yes & Yes & Yes & Yes & Yes & Yes \\
\hline Gender FEs & Yes & Yes & Yes & Yes & Yes & Yes \\
\hline Race FEs & Yes & Yes & Yes & Yes & Yes & Yes \\
\hline$R^{2}$ & 0.01 & 0.03 & 0.04 & 0.04 & 0.03 & 0.05 \\
\hline Observations & 10742 & 10545 & 10535 & 12196 & 11892 & 11878 \\
\hline
\end{tabular}

